\title{
Effect of different drying methods on anti-oxidation and anti-thrombosis activities of Salicornia europaea
}

\author{
Hwa-Jung Sung ${ }^{1}$, Deuk Hoi Kim ${ }^{2}$, Ho-Yong Sohn ${ }^{1 *}$ \\ ${ }^{1}$ Deptment of Food and Nutrition, Andong National University, Andong 36729, Korea \\ ${ }^{2}$ Research Center, Phyto Corporation, Seoul 08826, Korea
}

\section{함초의 건조방법에 따른 항산화 및 항혈전 활성의 변화}

\author{
성화정 ${ }^{1} \cdot$ 김득회 $^{2} \cdot$ 손호용 $^{1 *}$ \\ ${ }^{1}$ 안동대학교 식품영양학과, ${ }^{2}$ 파이토코퍼레이션
}

\begin{abstract}
The current study was performed to investigate the changes of bio-activities of Salicornia europaea (SE) depending on the different dry methods. The ethanol extracts were prepared from the freeze-drying SE (FD), hot-air drying SE (HD), and shade drying SE (SD). Their anti-oxidant and anti-thrombosis activities were compared. The yields of ethanol extraction in FD, HD, and SD were 14.4, 13.2 and 11.9\%, respectively. The highest contents of total polyphenol $(4.6 \mathrm{mg} / \mathrm{g})$ and total sugar $(23.4 \mathrm{mg} / \mathrm{g})$ were shown in $\mathrm{FD}$, whereas, the highest content of reducing sugar $(14.6 \mathrm{mg} / \mathrm{g})$ was observed in HD. In anti-oxidation activity assay, the FD and HD showed similar radical scavenging activities and reducing power. However, in SD, nitrite scavenging activity and reducing power were severely decreased. In anti-coagulation activity assay, the thrombin time (TT), prothrombin time (PT) and activated partial thromboplastin time (aPTT) of FD, HD and SD did not show significant changes at $5 \mathrm{mg} / \mathrm{mL}$ concentration. But the HD at $7 \mathrm{mg} / \mathrm{mL}$ had strong inhibitions against thrombin and blood coagulation factors. The platelet aggregation and hemolysis activities were not affected by dry methods. Our results suggest that both FD and HD are effective to maintain the functional ingredient of $\mathrm{SE}$, and $\mathrm{HD}$ is economic and efficient dry process for production of functional food.
\end{abstract}

Key words : Salicornia europaea, anti-oxidation, anti-thrombosis, freeze drying, hot-air drying

\section{서 론}

천연물의 저장성과 이용성을 증가시키고, 계절적, 공간 적, 시간적 제약을 극복하여 고부가가치 제품을 개발하고 자 하는 연구는 각각의 천연물의 효율적인 건조방법 선택 및 건조시의 품질변화에 대한 기초자료를 필수적으로 요구 한다. 현재까지 더덕(1), 양파(2), 고추가루(3), 보리잎(4), 허브류(5), 곤드레 나물(6), 산사과 열매(7), 포도씨(8), 삼채

*Corresponding author. E-mail : hysohn@anu.ac.kr Phone : 82-54-820-5491, Fax : 82-54-820-6281

Received 26 July 2016; Revised 2 August 2017; Accepted 10 August 2017.

Copyright (c) The Korean Society of Food Preservation. All rights reserved.
(9), 히카마(10), 아로니아(11), 오미자(12), 블루베리(13), 매 생이(14) 및 와송(15)과 같은 많은 식용, 약용식물에서의 다양한 건조방법 검토에 대한 연구 보고가 지속적으로 이루 어져 왔으며, 최근에는 건조시 이화학적 특성 분석에서 나 아가 건조처리에 따른 원료의 생리활성 변화에 대한 연구가 집중적으로 이루어지고 있다 $(5,9,17,20,22)$. 건조 천연물의 품질특성 평가는 매생이, 곤드레나물, 블루베리 및 히카마 와 같이 쉽게 건조하여 그대로 식품으로 이용되는 경우는 건조 시료를 그대로 사용하며 $(6,10,11,13,14)$, 포도씨, 삼채, 보리잎, 와송과 같이 그대로 식품으로 사용하기 어렵거나, 효능 평가가 필요한 경우는 건조 시료 추출물을 사용 $(4,7-9,15)$ 하고 있다. 이때, 추출용매로는 주로 물(7)과 ethanol이 이용되고 있으며, ethanol의 경우에는, $70 \%$ ethanol(8), $80 \%$ ethanol(4,9) 및 $95 \%$ ethanol(15)이 추출용매 
로 주로 이용되고 있는 실정이다.

한편, 함초는 갯벌, 염전에 서식하는 명아주과의 식물로 마디가 퉁퉁하고 튀어나온 모양을 하여, 국내에서는 퉁퉁 마디로도 불리며 특유의 짠맛과 풍부한 미네랄, 부드러운 식감으로 인해 4-6월에는 샐러드나 무침으로, 9-10월에는 거친 식감과 낮은 저장성으로 인해 건조 후 분말로 이용되 고 있다(16). 함초는 전체 지방산의 $50 \%$ 를 차지하는 리놀렌 산 및 총 아미노산의 $40 \%$ 이상을 차지하는 필수아미노산 및 지상부의 $60 \%$ 를 차지하는 식이섬유 함유로 인해 영양성 이 우수하면서도(17) 배변촉진, 위장병 치료에 효과적임이 알려져 있으며(18), 최근에는 함초의 $\mathrm{Na}^{+}, \mathrm{K}^{+}, \mathrm{Mg}^{++}, \mathrm{Ca}^{++}$ 등의 미네랄을 이용하는 식물성 소금 개발 $(19,20)$, 항산화 $(16,21,22)$, 항당뇨(23), 고지혈증(23), 항염증(24), 항혈전 $(22,25,26)$, 항주름(27), 비만 억제(28), 면역능 증강(29) 및 암세포 성장억제능(30)이 보고되면서 수요가 증가하고 있 다. 함초는 $90 \%$ 이상의 수분함량을 가지며, 갯벌 유래의 다양한 세균, 곰팡이에 오염되어 있어 변패 및 부패에 매우 취약하여 사용직전까지 냉동보관하게 된다. 그러나 냉동저 장의 경우 다량의 해동드립 및 물성 변화의 문제가 있으며, 재배지에서는 음건 및 천일건조를 이용하고 있다(17). 그러 나 현재까지 함초의 건조방법에 따른 유용 생리활성의 변화 에 대한 연구는 이루어진 바 없는 실정이다. 본 연구에서는 함초를 이용한 항산화, 항혈전 기능성 음료 개발을 위해, 함초를 각각 동결건조, 열풍건조 및 음건하고 이의 에탄올 추출물을 조제하여 건조방법에 따른 함초의 성분변화, 항 산화 및 항혈전 활성 변화를 평가하여, 가장 효과적인 건조 방법을 제시하고 함초를 이용한 기능성 식품소재 개발의 기초자료로 활용하고자 하였다.

\section{재료 및 방법}

\section{실험재료 및 시약}

본 실험에 사용된 함초는 전남 신안군 함초 재배농가에 서 2015년 9월 및 2016년 10월에 수확한 함초를 구입하여 사용하였다. 동결건조의 경우, 이물질을 제거한 함초를 3 $\mathrm{cm}$ 정도로 세절하고 이를 $-40^{\circ} \mathrm{C}$ 초저온 냉장고에서 예비동 결한 후, 동결건조기(일신바이오베이스 PVTFD-100R, Dongducheon, Korea)에 넣어 건조하였으며, $-40^{\circ} \mathrm{C}$ 에서 시 작하여 $15^{\circ} \mathrm{C} / 200$ 분씩 온도를 증가시켜 운전하고 최종적으 로는 $25^{\circ} \mathrm{C}$ 에서 80 시간 건조하였다. 열풍건조의 경우, 이물 질을 제거한 상기 세절 함초를 $60^{\circ} \mathrm{C}$ 의 열풍건조기에 넣고 2 일간 항량 건조하였으며, 음건의 경우 세절 함초를 $25^{\circ} \mathrm{C}$ 의 실온에서 7일간 항량 건조하였다. 각각의 건조 함초는 50-100 mesh로 분쇄하여 추출에 사용하였으며, $95 \%$ ethanol(Daejung Chemicals \& Metals Co., Ltd., Cheongju, Korea)을 시료 무게의 10 배 되도록 가하여 상온에서 3회
추출하였다. 이후 추출액은 filter paper(Whatsman No. 2)로 거른 후 감압 농축(Eyela Rotary evaporator N-1000, Tokyo Rikakikai Co., Ltd., Tokyo, Japan)하여 분말로 조제하였다. 이후 분말시료들은 $\mathrm{DMSO}$ 에 적당한 농도로 녹여, 성분 분 석, in vitro 항산화 활성, 항혈전 활성 및 적혈구 용혈 활성 평가에 사용하였다. 항혈전 활성평가에 사용한 혈장은 시 판 control plasma(MD Pacific Technology Co., Ltd., Tianjin, China)를 사용하였으며, PT reagent와 aPTT reagent는 $\mathrm{MD}$ Pacific Hemostasis(MD Pacific Technology Co.)의 분석시약 을 사용하여 측정하였다(30). 기타 사용한 시약은 시약급 이상으로 Sigma Co.(St. Louis, MO, USA)의 제품을 구입하 여 사용하였다. 실험에 사용한 함초 시료는 안동대학교 식 품영양학과에서 보관하고 있다(voucher specimen 2015SEFD).

\section{항산화 활성 평가}

다양한 건조법으로 조제된 함초의 에탄올 추출물의 항산 화 활성은 1,1-diphenyl-2-picryl hydrazyl(DPPH) anion scavenging activity(DSA), 2,2-azobis(3-ethylbenzothiazoline6-sulfonate)(ABTS) cation scavenging activity(ASA), nitrite scavenging activity(NSA) 및 환원력 측정으로 평가하였다 (31). 활성 평가는 기존의 방법(30)과 동일하게 사용하였으 며, 대조구로는 vitamin C(Sigma Co.)를 사용하였으며, 용매 대조구로는 $\mathrm{DMSO}$ 를 사용하였다. 각각의 활성 평가는 각 각 3회 반복한 실험의 평균과 편차로 표시하였다.

\section{항응고 활성}

혈전 생성과정중의 혈액응고는 다양한 coagulation factors, prothrombin, thrombin의 순차적 cascade 응고반응 에 의해 진행되므로, 함초의 혈액응고저해 활성은 thrombin time(TT), prothrombin time(PT) 및 activated partial thromboplastin time(aPTT) 을 측정하여 평가하였다(31). TT 는 $37^{\circ} \mathrm{C}$ 에서 $0.5 \mathrm{U}$ thrombin(Sigma Co.) $50 \mu \mathrm{L}$ 와 $20 \mathrm{mM}$ $\mathrm{CaCl}_{2} 50 \mu \mathrm{L}$, 다양한 농도의 시료 $10 \mu \mathrm{L}$ 를 Amelung coagulometer KC-1A(Amelung. Lemgo, Germany)의 튜브에 혼합하여 2분간 반응시킨 후, 혈장 $100 \mu \mathrm{L}$ 를 첨가한 후 혈장이 응고될 때까지의 시간을 측정하였으며, 시료 대조 군으로는 아스피린(Sigma Co.)을, 그리고 용매 대조군으로 는 $\mathrm{DMSO}$ 를 사용하였다. Thrombin 저해 활성은 3회 이상 반복한 시료 TT 실험의 평균치를 용매 대조구인 $\mathrm{DMSO}$ 의 $\mathrm{TT}$ 평균치의 비로 나타내었다(32). 한편 PT 측정은 혈장 $70 \mu \mathrm{L}$ 와 다양한 농도의 시료 $10 \mu \mathrm{L}$ 를 coagulometer 의 튜브 에 첨가하여 $37^{\circ} \mathrm{C}$ 에서 3 분간 가온 후, $130 \mu \mathrm{L}$ 의 PT reagent 를 첨가하고 혈장이 응고될 때까지의 시간을 3회 반복한 실험의 평균치로 나타내었으며, prothrombin 저해 활성은 3회 이상 반복한 시료 PT 실험의 평균치를 $\mathrm{DMSO}$ 의 $\mathrm{PT}$ 평균치의 비로 나타내었다(32). aPTT 측정의 경우에는, 표 
준혈장 $70 \mu \mathrm{L}$ 와 다양한 농도의 시료 $10 \mu \mathrm{L}$ 를 coagulometer 튜브에 첨가하여 $37^{\circ} \mathrm{C}$ 에서 3 분간 가온 후, $65 \mu \mathrm{L}$ 의 aPTT reagent를 첨가하고 다시 $37^{\circ} \mathrm{C}$ 에서 3 분간 반응하였다. 이후 $65 \mu \mathrm{L} \mathrm{CaCl}(35 \mathrm{mM})$ 을 첨가한 후 혈장이 응고될 때까지의 시간을 3회 반복한 실험의 평균치로 나타내었으며, aPTT 연장 활성은 3 회 이상 반복한 시료 $\mathrm{aPTT}$ 실험의 평균치를 $\mathrm{DMSO}$ 의 $\mathrm{aPTT}$ 평균치의 비로 나타내었다(32).

\section{혈소판 응집 저해 활성}

혈소판 응집은 혈전 생성의 최초반응이면서 1 차 지혈 플러그를 생성하여 혈전 생성을 가속화시키는 중요한 반응 이다. 혈소판 응집저해 정도는 혈소판이 미세전극에 부착, 응집됨에 따라 발생하는 전기 저항값의 변화를 Whole Blood Aggregometer(Chrono-log, PA, USA)를 사용하여 측 정하는 impedance 법으로 평가하였다(33). 먼저 인간 농축 혈소판(platelet rich plasma, PRP)을 전처리 및 수세한 후 최종 혈소판 농도가 $5 \times 10^{8} \mathrm{cells} / \mathrm{mL}$ 이 되도록 조정하여 사 용하였으며, 응집유도제로 collagen $(1 \mathrm{mg} / \mathrm{mL})$ 을 사용하였 다. 응집반응은 collagen 첨가 후 12 분간 측정하였으며 amplitude, slope, area under 를 측정하여 평가하였다 $(30,31)$ 시료의 혈소판 응집 저해 활성은 시료 대신 $\mathrm{DMSO}$ 를 첨가 한 대조구와의 상대적인 area under값의 비로 나타내었다.

\section{인간 적혈구 용혈 활성 평가}

다양한 건조법으로 조제된 함초의 에탄올 추출물의 안전 성 평가의 일환으로 인간 적혈구(4\%)를 이용하여 용혈 활 성을 평가하였다. PBS로 3회 수세한 인간 적혈구 $100 \mu \mathrm{L}$ 를 96-well microplate에 가하고 다양한 농도의 시료용액 100 $\mu \mathrm{L}$ 를 가한 다음 $37^{\circ} \mathrm{C}$ 에서 30 분간 반응시켰으며, 이후, 반응 액을 10 분간 원심분리 $(1,500 \mathrm{rpm})$ 하여 상등액 $100 \mu \mathrm{L}$ 를 새로운 microtiter plate로 옮긴 후 용혈에 따른 헤모글로빈 유출 정도를 $414 \mathrm{~nm}$ 에서 측정하였다(31). 시료의 용매 대조 구로는 $\mathrm{DMSO}(2 \%)$ 를 사용하였으며, 적혈구 용혈을 위한 실험 대조구로는 triton X-100 및 amphotericin B를 사용하였 다. 용혈활성은 다음의 수식을 이용하여 계산하였다.

$$
\text { Hemolytic activity }(\%)=\left(\frac{\text { Abs. S-Abs. C }}{\text { Abs. T-Abs. C }}\right) \times 100
$$

Abs. S : 시료 첨가구의 흡광도

Abs. C : DMSO 첨가구의 흡광도

Abs. T : triton X-100 첨가구의 흡광도

\section{기타 분석}

Total flavonoid(TF) 및 total polyphenol(TP) 함량 측정은 기존의 보고된 방법(34)에 따라 측정하였으며, 각각 rutin과 tannic acid를 표준시약으로 사용하였다(31). 총당 정량의
경우에는 phenol-sulfuric acid법을, 환원당 정 량의 경우에는 DNS 변법을 이용하였다(35). 각각의 분석결과는 3 회 반복 한 실험의 평균과 편차로 나타내었다.

\section{통계분석}

실험 결과는 SPSS 23.0 버전을 사용하여 mean \pm SD 로 나타내었으며, 각 군간의 차이는 ANOVA로 분석하였으며, Duncan 다중비교 검증법으로 통계적 유의성 검정을 조사 하였다. 유의수준은 $p<0.05$ 로 하였다.

\section{결과 및 고찰}

\section{동결건조, 열풍건조 및 음건 시료의 ethanol 추출물 조제} 및 이의 성분 분석

동결건조, 열풍건조 및 음건하여 제조된 함초 시료의 최 종 수분함량은 각각 $5.7 \%, 7.2 \%$, 및 $9.35 \%$ 를 나타내었다. 동결건조 시료는 건조 후 색상을 유지한 반면 열풍건조 및 음건 시료는 함초의 푸른색이 감소되고 부분적인 갈변이 나타났다. 동결건조, 열풍건조 및 음건 시료의 ethanol 추출 효율은 각각 $14.4,13.2,11.9 \%$ 를 나타내어 동결건조시 수율 이 음건에 비해 1.2 배 높았다(Table 1). 각각의 건조시료의 ethanol 추출물의 TP 함량 분석결과, 열풍건조 시료에서 가장 높은 $4.6 \mathrm{mg} / \mathrm{g}$ 을 보였으며, 음건에서 가장 낮은 3.2 $\mathrm{mg} / \mathrm{g}$ 함량을 나타내었다. 반면 $\mathrm{TF}$ 함량은 $4.2-4.4 \mathrm{mg} / \mathrm{g}$ 을 나타내어 유의적인 변화를 나타내지 않았다. 이는 기존의 더덕(1), 산사과(7), 포도씨(8) 등의 동결건조시 열풍건조보 다 높은 폴리페놀 함량을 나타낸다는 기존의 보고와 동일한 경향이었다. 한편 총당 분석결과 동결건조 시료에서 23.4 $\mathrm{mg} / \mathrm{g}$ 으로 가장 높게 나타났으며, 열풍건조 시료에서 20.5 $\mathrm{mg} / \mathrm{g}$ 및 음건시료에서 $12.5 \mathrm{mg} / \mathrm{g}$ 을 나타내어 함초의 열풍 건조 및 음건시에 총당의 감소가 나타남을 알 수 있었다. 환원당 분석결과, 열풍건조 시료에서 $14.6 \mathrm{mg} / \mathrm{g}$ 의 가장 높 은 값을 나타내어, 동결건조시료의 $6.5 \mathrm{mg} / \mathrm{g}$, 음건시료의 $4.4 \mathrm{mg} / \mathrm{g}$ 에 비해 2.2-3.3배 높게 나타났다. 이러한 결과는 함초의 폴리페놀 및 총당 함량은 열풍건조 및 음건시에 유의적으로 감소되며, 환원당 함량은 열풍건조시에 증가되 나, 음건시에는 유의적으로 감소됨을 의미하고 있다.

Table 1. Extraction yields and component analysis of the ethanol extracts of Salicornia europaea prepared by different dry methods

\begin{tabular}{cccccc}
\hline \multirow{2}{*}{ Samples } & \multirow{2}{*}{$\begin{array}{c}\text { Extraction } \\
\text { yield (\%) }\end{array}$} & $\begin{array}{c}\text { Total } \\
\text { Polyphenol }\end{array}$ & $\begin{array}{c}\text { Total } \\
\text { flavonoid }\end{array}$ & $\begin{array}{c}\text { Total } \\
\text { sugar }\end{array}$ & $\begin{array}{c}\text { Reducing } \\
\text { sugar }\end{array}$ \\
\hline Freeze drying & 14.4 & $4.6 \pm 0.1^{\mathrm{al})}$ & $4.2 \pm 0.2^{\mathrm{a}}$ & $23.4 \pm 0.0^{\mathrm{a}}$ & $6.5 \pm 0.9^{\mathrm{b}}$ \\
Hot-air drying & 13.2 & $4.0 \pm 0.4^{\mathrm{b}}$ & $4.3 \pm 0.2^{\mathrm{a}}$ & $20.5 \pm 0.9^{\mathrm{b}}$ & $14.6 \pm 1.0^{\mathrm{c}}$ \\
Shade drying & 11.9 & $3.2 \pm 0.3^{\mathrm{c}}$ & $4.4 \pm 0.4^{\mathrm{a}}$ & $12.5 \pm 0.4^{\mathrm{c}}$ & $4.4 \pm 0.2^{\mathrm{a}}$ \\
\hline
\end{tabular}

${ }^{11}$ Different superscripts within a column differ significantly $(\mathrm{p}<0.05)$. 
함초 동결건조, 열풍건조 및 음건 시료의 항산화 활성 다양한 함초 건조시료의 항산화 활성 평가를 위해 $\mathrm{DPPH}$, $\mathrm{ABTS}$ 및 nitrite 소거능 및 환원력을 평가하였다. 그 결과 $0.5 \mathrm{mg} / \mathrm{mL}$ 농도에서 동결건조 시료는 $2.8 \%, 21.7 \%, 0.041$ 의 $\mathrm{DSA}, \mathrm{ASA}$ 및 환원력을 나타내었으며, $0.2 \mathrm{mg} / \mathrm{mL}$ 농도에서 $41.1 \%$ 의 NSA를 나타내어, 양이온 소거능과 nitrite 소거능 이 우수하였다. 반면, 열풍건조 시료는 상기 농도에서 DSA 는 인정되지 않았으며, $21.3 \%$ 의 ASA, $42.9 \%$ 의 NSA 및 0.079 의 환원력을 나타내어 동결건조와 유사한 라디컬 소 거능을 나타내었다(Table 2). 반면 음건한 경우 ASA는 $28.1 \%$ 로 다소 증가하였으나, NSA 활성은 오히려 $17.2 \%$ 로 감소하였으며, 환원력도 나타나지 않았다.

Table 2. Anti-oxidation activities of the ethanol extracts of Salicornia europaea prepared by different dry methods

\begin{tabular}{|c|c|c|c|c|}
\hline \multirow{2}{*}{ Samples } & \multicolumn{3}{|c|}{ Radical scavenging activity ${ }^{1)}(\%)$} & \multirow{2}{*}{$\begin{array}{l}\text { Reducing power } \\
(0.5 \mathrm{mg} / \mathrm{mL})\end{array}$} \\
\hline & DPPH & ABTS & Nitrite & \\
\hline Freeze drying & $2.8 \pm 0.7^{\mathrm{a} 2)}$ & $21.7 \pm 2.7^{\mathrm{a}}$ & $41.1 \pm 1.9^{\mathrm{a}}$ & $0.041 \pm 0.001^{\mathrm{a}}$ \\
\hline Hot-air & $-2.5 \pm 3.8^{\mathrm{a}}$ & $21.3 \pm 0.6^{\mathrm{a}}$ & $42.9 \pm 1.6^{\mathrm{a}}$ & $0.079 \pm 0.001^{\mathrm{b}}$ \\
\hline Shade drying & $-0.7 \pm 4.0^{\mathrm{a}}$ & $28.1 \pm 1.4^{b}$ & $17.2 \pm 2.3^{\mathrm{b}}$ & $-0.009 \pm 0.001^{\mathrm{c}}$ \\
\hline
\end{tabular}

${ }^{11}$ Radical scavenging activity: The concentrations used for DPPH and ABTS scavenging activity assay, and nitrite scavenging activity assay were $0.5 \mathrm{mg} / \mathrm{mL}$ and $0.2 \mathrm{mg} / \mathrm{mL}$, respectively.

${ }^{2)}$ Different superscripts within a column differ significantly $(\mathrm{p}<0.05)$.

한편 함초 건조시료들의 다양한 농도에서의 항산화능 평가 결과를 바탕으로 $\mathrm{RC}_{50}$ 을 계산하였으며, 그 결과는 Table 3에 나타내었다. ASA의 경우 함초 음건시료에서 가 장 낮은 $950.8 \mathrm{mg} / \mathrm{mL}$ 의 $\mathrm{RC}_{50}$ 을, $\mathrm{NSA}$ 의 경우 열풍건조 시료 에서 가장 낮은 $235.7 \mathrm{mg} / \mathrm{mL}$ 의 $\mathrm{RC}_{50}$ 을 확인하였다. 이러한 결과는 건조방법에 따라 함초의 항산화 활성의 변화가 나타 날 수 있음을 의미하나, 열풍건조 시료에서 동결건조 시료 와 유사한 항산화 활성을 유지하고 있음을 알 수 있다.

Table 3. The calculated $\mathrm{RC}_{50} \mathrm{~S}$ of the ethanol extracts of Salicornia europaea prepared by different dry methods

\begin{tabular}{cccc}
\hline \multirow{2}{*}{ Samples/Chemical } & \multicolumn{3}{c}{$\mathrm{RC}_{50}{ }^{1)}(\mathrm{mg} / \mathrm{mL})$} \\
\cline { 2 - 4 } & $\mathrm{DPPH}$ & $\mathrm{ABTS}$ & Nitrite \\
\hline Freeze drying & $\mathrm{NC}^{2)}$ & $1,315.2$ & 384.2 \\
Hot-air drying & $\mathrm{NC}$ & $1,552.5$ & 235.7 \\
Shade drying & $\mathrm{NC}$ & 950.8 & 626.6 \\
Vitamin C & 11.0 & 3.4 & 9.2 \\
\hline
\end{tabular}

${ }^{1)} \mathrm{RC}_{50}$, The concentration required to scavenger $50 \%$ of particular radical under the standard conditions.

${ }^{2)} \mathrm{NC}$, Not calculated. Different superscripts within a column differ significantly $(\mathrm{p}<0.05)$

\section{함초 동결건조, 열풍건조 및 음건 시료의 혈액응고저해 활성}

성숙 함초의 트롬빈 및 혈액응고인자 저해(25) 및 효소처 리 함초 methanol 추출물의 혈액응고인자 저해(22)는 최근 보고된 바 있으나, 다양한 건조과정 이후의 항혈전 활성 변화는 알려져 있지 않은 상태이다. 따라서, 다양한 동결건 조, 열풍건조 및 음건 함초 시료의 항응고 활성을 TT, PT, $\mathrm{aPTT}$ 를 각각 측정하여 평가하였으며, 그 결과는 Fig. 1에 나타내었다. 먼저 대조구로 사용된 $\operatorname{aspirin}(1.5 \mathrm{mg} / \mathrm{mL})$ 은 무처리구에 비해 TT는 2.09배, PT는 1.23배, aPTT는 1.38배 연장시켜 우수한 혈액응고저해 활성을 나타내었다. 동결건 조 함초 시료는 $5 \mathrm{mg} / \mathrm{mL}$ 농도에서 TT는 1.92 배, PT는 1.06 배, aPTT는 1.12 배 연장시켜 양호한 트롬빈 저해 활성을 나타내었다. 이러한 항응고 활성은 농도 의존적으로 증가 되었으며, 건조과정을 거치치 않은 함초 에탄올 추출물의
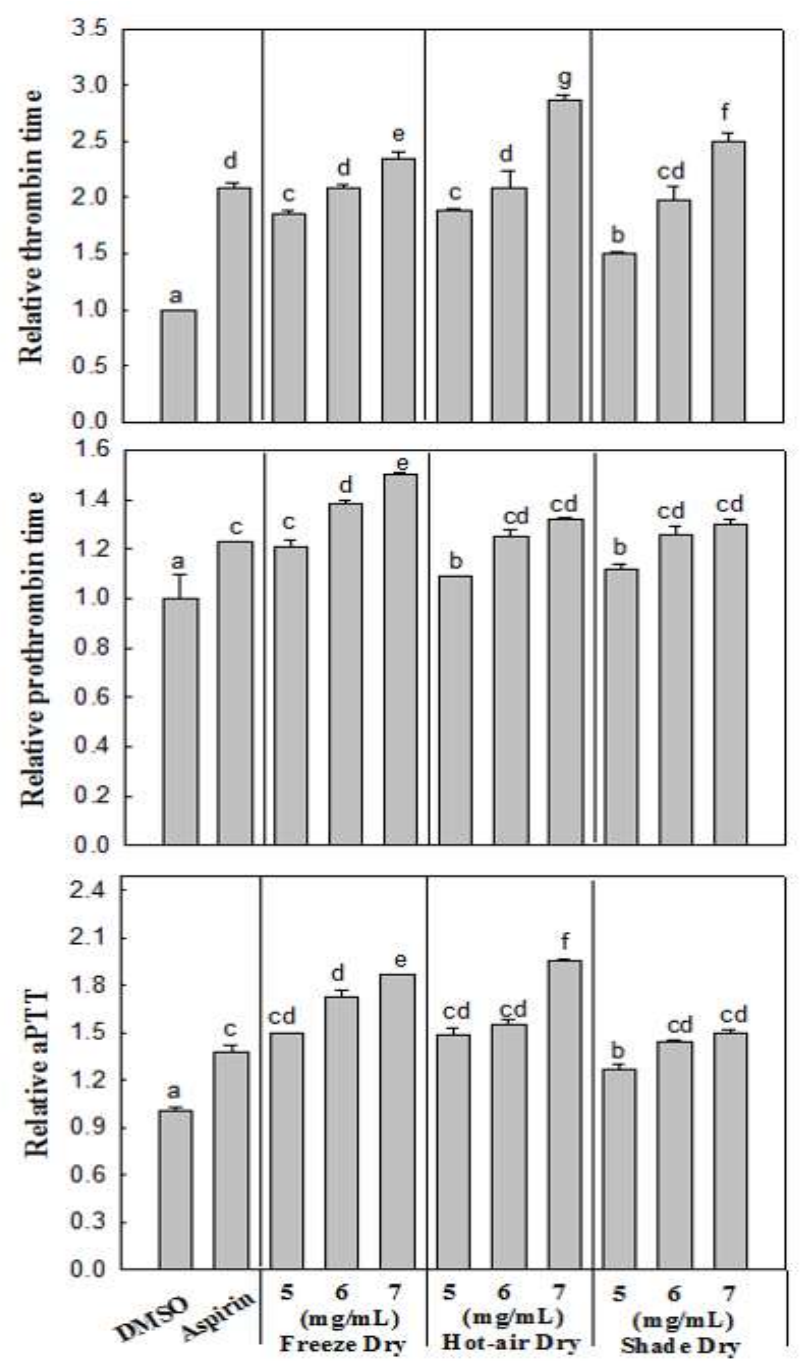

Fig. 1. Effect of the ethanol extracts of Salicomia europaea prepared by different dry methods on blood coagulation. Relative TT, PT, and aPTT are dimensionless. 
항응고 활성과 유사하였다(25). 열풍건조 시료의 경우, 5 $\mathrm{mg} / \mathrm{mL}$ 농도에서 TT는 1.89 배, PT는 1.09배, aPTT는 1.48 배 연장시켜 $\mathrm{aPTT}$ 에서만 활성 증가가 나타났으며, 농도 의존 적인 항응고 활성이 나타났다. 한편 음건 시료의 경우 5 $\mathrm{mg} / \mathrm{mL}$ 농도에서 TT는 1.50 배, PT는 1.12배, aPTT는 1.27 배 연장시켜, 동결건조시료에 TT의 감소가 확인되었다. 특이 한 점은 열풍건조 시료의 $7 \mathrm{mg} / \mathrm{mL}$ 처리시, TT 및 $\mathrm{aPTT}$ 를 각각 2.87 및 1.95 배 연장시켜, 동일농도의 동결건조 시료에 비해서도 유의적으로 항응고 활성의 증가가 나타났다(Fig. 1). 이러한 결과는, 함초의 항응고 활성 물질은 열풍건조시 에 손실되지 않으며, 열풍건조시 동결건조와 유사한 항응 고 활성을 나타냄을 의미한다.

\section{함초 동결건조, 열풍건조 및 음건 시료의 혈소판 응집저 해 활성}

성숙 함초의 에탄올 추출물이 $0.25 \mathrm{mg} / \mathrm{mL}$ 농도에서 140-150\%의 혈소판 응집도를 나타낸다는 최근 보고(25)가 있으나, 다양한 건조과정 이후 함초의 혈소판 응집활성에 대해 알려진 바는 없다. 따라서 동결건조, 열풍건조 및 음건 함초의 에탄올 추출물을 대상으로 인간 혈소판 응집능을 평가하였다. 먼저 혈소판 응집저해제인 아스피린(0.25 $\mathrm{mg} / \mathrm{mL}$ )은 amplitude $9 \Omega$, area under 47.8 로, 무첨가구 $\mathrm{DMSO}$ 의 $21 \Omega$, area under 130.6 에 비해 각각 $42.8 \%$ 및 $36.6 \%$ 의 감소된 값을 나타내었다. 아스피린은 농도 의존적 인 혈소판 응집저해 활성을 나타내었다(Table 4, Fig. 2).

Table 4. Effect of the ethanol extracts of Salicornia europaea prepared by different dry methods on human platelet aggregation

\begin{tabular}{|c|c|c|c|c|c|c|}
\hline Sample/Chemicals & Conc. (mg/mL) & Amplitude (ohm) & Slope & Lag time (sec) & Area under & $\operatorname{PAA}^{1)}(\%)$ \\
\hline \multirow{2}{*}{ DMSO } & - & 21 & 3 & 62 & 130.6 & 100.0 \\
\hline & - & 21 & 3 & 69 & 130.5 & 100.0 \\
\hline \multirow{3}{*}{ Aspirin } & 0.50 & 4 & 0 & 119 & 22.2 & 17.0 \\
\hline & 0.25 & 9 & 1 & 80 & 47.8 & 36.6 \\
\hline & 0.125 & 13 & 2 & 82 & 69.0 & 52.9 \\
\hline Freeze drying & 0.25 & 28 & 4 & 23 & 187.9 & 143.9 \\
\hline Hot-air drying & 0.25 & 25 & 4 & 26 & 181.6 & 139.1 \\
\hline Shade drying & 0.25 & 28 & 4 & 22 & 179.7 & 137.6 \\
\hline
\end{tabular}

${ }^{1)}$ PAA, platelet aggregation activity. Data are presented as representative result relative of independent three determinations. Amplitude is expressed as ohms by maximum extent of platelet aggregation, and slope (rate of reaction) is determined by drawing a tangent through the steepest part of curve. Area under is a calculated area in descent drawing during platelet aggregation.

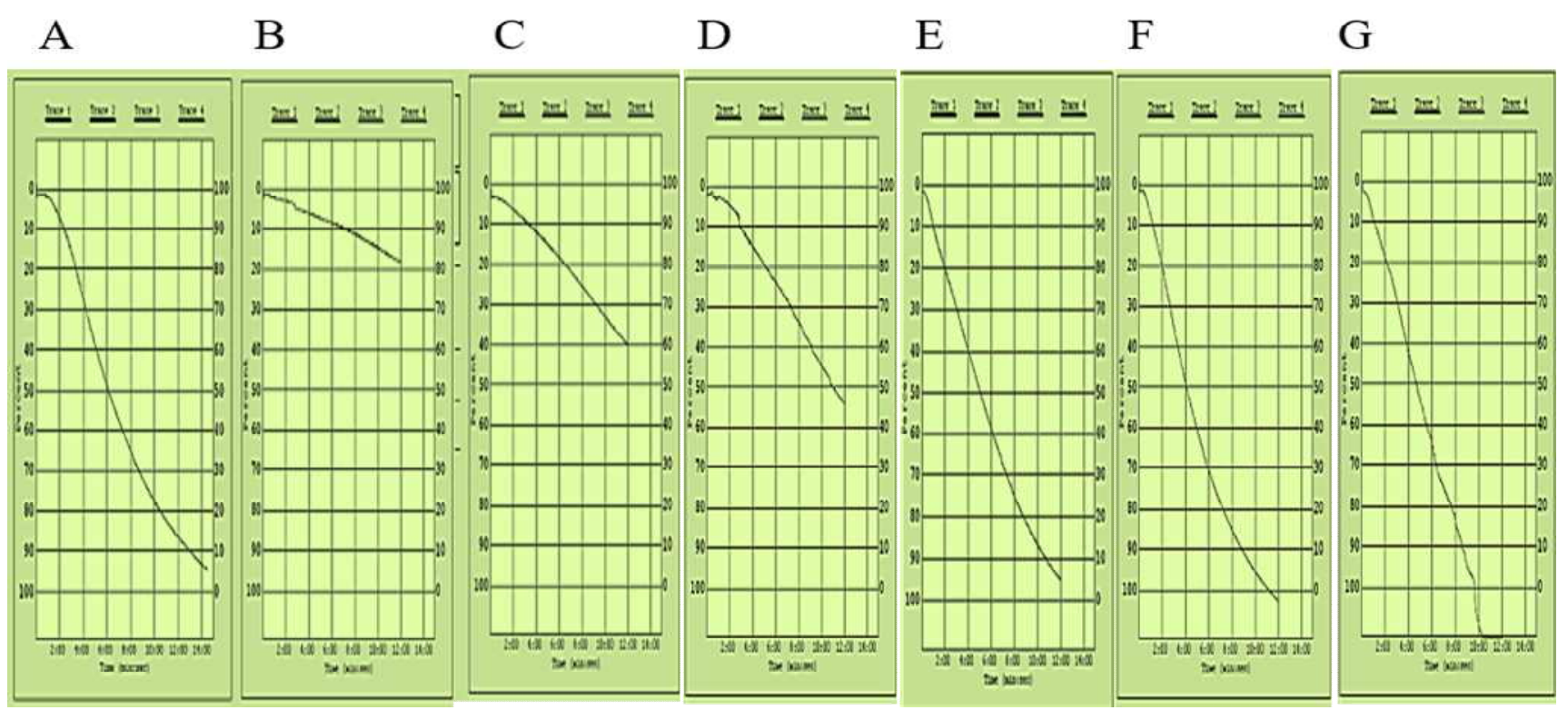

Fig. 2. Diagram of impedance changes during platelet aggregation after addition of aspirin and the ethanol extracts of Salicornia europaea prepared by different dry methods.

A, DMSO; B, aspirin $(0.5 \mathrm{mg} / \mathrm{mL})$; C, aspirin $(0.25 \mathrm{mg} / \mathrm{mL})$; D, aspirin $(0.125 \mathrm{mg} / \mathrm{mL})$; E, freeze dried; F, hot-air dried; G, shade dried Salicornia europaea. Aggregation was induced by addition of $2.5 \mu \mathrm{L}$ of collagen $(1 \mathrm{mg} / \mathrm{mL})$ into cuvette containing $50 \mathrm{\mu L}$ of washed PRP and measured the impedance change for 12 min. 
한편 동결건조, 열풍건조 및 음건 시료에서는 각각 187.9 , 181.6 및 179.7의 area under를 나타내어, 혈소판 응집도는 각각 $143.9,139.1$ 및 $137.1 \%$ 로 나타났다. 이러한 결과는 열풍건조 및 음건시에 혈소판 응집에 관련되는 성분의 변화 는 거의 없음을 의미한다.

함초 동결건조, 열풍건조 및 음건 시료의 적혈구 용혈활성 다양한 함초 건조 시료들의 적혈구 용혈활성을 평가한 결과는 Table 5에 나타내었다. 대조구로 사용된 DMSO는 용혈활성이 없었으며, triton X-100은 $1 \mathrm{mg} / \mathrm{mL}$ 농도에서, amphotericin B는 $0.02 \mathrm{mg} / \mathrm{mL}$ 에서 적혈구를 $100 \%$ 용혈시 킨 반면, 동결건조, 열풍건조 및 음건 함초 시료의 ethanol 추출물은 $1 \mathrm{mg} / \mathrm{mL}$ 농도까지 용혈활성이 전혀 나타나지 않았다. 따라서 함초는 다양한 건조과정에서 추가적인 적 혈구 용혈 문제는 나타내지 않으리라 판단되었다. 이상의 결과는, 함초 재배 농가에서 일반적으로 사용하는 천일건 조 및 음건보다는 열풍건조 또는 동결건조가 함초의 유용성 분, 항산화 및 항혈전 활성 유지측면에서 유리하며, 특히 동결건조 및 열풍건조시 성분 및 활성의 변화가 거의 없으 며, 열풍건조가 동결건조보다 훨씬 경제적임을 감안한다 면, 오히려 함초의 경우 열풍건조가 유리함을 제시하고 있 다. 특히 함초의 항혈전 활성을 이용하는 기능성 음료를 제조하고자 하는 경우 열풍건조를 이용하는 것이 경제적이 면서 효과적임을 제시하고 있다.

Table 5. Hemolytic activity of the ethanol extracts of Salicornia europaea prepared by different dry methods against human red blood cell (hRBC)

\begin{tabular}{cc}
\hline Chemicals/Samples (mg/mL) & Hemolysis against hRBC $(\%)$ \\
\hline DMSO & $-0.6 \pm 1.6^{1) 22}$ \\
Triton-X 100 (1.0). & $100.4 \pm 1.4^{\mathrm{b}}$ \\
Amphotericin B (0.02) & $100.8 \pm 2.5^{\mathrm{b}}$ \\
Freeze drying (1.0) & $-2.1 \pm 0.1^{\mathrm{a}}$ \\
Hot-air drying (1.0) & $-0.8 \pm 0.8^{\mathrm{a}}$ \\
Shade drying (1.0) & $2.3 \pm 2.0^{\mathrm{a}}$ \\
\hline
\end{tabular}

${ }^{1)}$ Data are presented as the mean $\pm \mathrm{SD}$ of three determinations. Hemolytic activity was evaluated using $4 \%$ human red blood cell and the relative hemolysis $(\%)$ was calculated by following equation.

${ }^{2)}$ Different superscripts within a column differ significantly $(\mathrm{p}<0.05)$.

Hemolytic activity(\%)=[(Abs. S-Abs. C)/(Abs. T-Abs. C)] $\times 100$ (For Abs. S, Abs. $\mathrm{C}$ and Abs.T, refer the materials and methods).

\section{요 약}

식용 및 약용으로 이용되고 있는 함초를 이용한 고부가 가치 제품개발을 위해, 동결건조, 열풍건조, 음건한 함초의 ethanol추출물을 조제하여 건조방법에 따른 성분 변화, 항 산화 및 항혈전 활성 변화를 평가하였다. 동결건조, 열풍건
조 및 음건 시료의 ethanol 추출효율은 각각 $14.4,13.2$, $11.9 \%$ 를 나타내어 동결건조시 수율이 음건에 비해 1.2 배 높았다. 성분 분석결과, 동결건조 시료의 total polyphenol 함량은 $4.6 \mathrm{mg} / \mathrm{g}$ 으로 열풍건조 및 음건 시료보다 높았으며, total flavonoid 함량은 건조방법과 무관하게 $4.2-4.4 \mathrm{mg} / \mathrm{g}$ 을 나타내었다. 반면 총당 함량은 동결건조에서 가장 높게 나 타났으며, 음건 시료는 동결건조 시료에 비해 $53 \%$ 수준을 나타내었다. 환원당의 경우 열풍건조시료에서 가장 높게 나타났으며, 음건시료에 비해 3.3배 높게 나타났다. 항산화 활성 평가결과, 동결건조, 열풍건조 시료에서는 유사한 항 산화 활성이 나타났으나, 음건 시료의 경우 환원력과 nitrite 소거능은 유의적으로 감소되었다. 항응고 활성의 경우, 모 든 건조 시료에서 농도 의존적인 우수한 항응고 활성을 나타내었으며, 특히 열풍건조 시료에서 강력한 TT 및 aPTT 연장 활성을 나타내었다. 인간 혈소판에 대한 응집저해 활 성과 적혈구 용혈활성은 건조방법에 따른 유의적인 변화는 나타나지 않았다. 본 연구결과는 함초의 유용 기능성 유지 를 위해 열풍건조 및 동결건조가 필요하며, 특히 함초의 항혈전 활성을 이용하는 기능성 식품을 제조하고자 하는 경우 열풍건조를 이용하는 것이 경제적이면서 효과적임을 제시하고 있다.

\section{감사의 글}

본 연구는 2015년도 농림축산식품부 고부가가치식품기 술개발사업(과제번호 115008-2)의 의해 수행되었으며, 이 에 감사드립니다.

\section{References}

1. Jin TY, Quan WR, Wang MH (2008) Changes of physicochemical and sensory characteristics in the Codonopsis lanceolata Saengsik, uncooked food by different drying methods. Korean J Food Sci Technol, 40, 721-725

2. Kang NS, Kim JH, Kim JK (2007) Modification of quality characteristics of onion powder by hot-air, vacuum and freeze drying methods. Korean J Food Preserv, 14, 61-66

3. Lim YR, Kyung YN, Jeong HS, Kim HY, Hwang IG, Yoo SM, Lee JS (2012) Effects of drying methods on quality of red pepper powder. J Korean Soc Food Sci Nutr, 41, 1315-1319

4. Park SJ, Lee JS, Hoe YH, Moon EY, Kang MH (2008) Physiology activity of barley leaf using different drying methods. J Korean Soc Food Sci Nutr, 37, 1627-1631 
5. Choi IY, Song YJ, Choi DC, Lee WH (2010) A comparative study for obtaining maximum essential oil from six herbs on the basis of harvesting time, cultivation regions \& type, and drying methods. Kor J Hort Sci Technol, 28, 492-496

6. Park SJ, Lee DW, Park SH, Rha YA (2016) Quality characteristics of Cirsium setidens Nakai by different drying method. Culi Sci Hos Res, 22, 104-114

7. Nam S, Kwon YR, Chung HS, Youn KS (2016) Antioxidant abilities and physiological properties of dried haw extracts prepared using different drying methods. Korean J Food Preserv, 23, 246-251

8. Jeong DS, Youn KS (2016) Comparison of the antioxidant and physiological activities of grape seed extracts prepared with different drying methods. Korean J Food Preserv, 23, 1-6

9. Lee JM (2016) Physicochemical and antioxidant properties in Allium hookeri by hot air-and freeze-drying methods. Korean J Food Preserv, 23, 57-62

10. Choi SI, Lee JH, Cho ML, Shin GH, Kim JM, Oh JW, Jung TD, Rhee SK, Lee OH (2015) Changes of quality characteristics of Jicama (Pachyrhizus erosus) potato powder by drying methods. Korean J Food Preserv, 22, 915-919

11. Lee S, Kim JK (2015) Quality characteristics of Aronia melanocarpa by different drying method. Korean J Food Preserv, 22, 56-62

12. Lee S, Moon HK, Lee SW, Moon JN, Kim JK (2014) Effects of drying methods on quality characteristics and antioxidative effects of Omija (Schizandra chinesis bailon). Korean J Food Preserv, 21, 341-349

13. Park SJ, Choi YB, Ko JR, Rha YA, Lee HY (2014) Effects of drying methods on the quality and physiological activities of blueberry (Vaccinium ashei). Korean J Culinary Res, 20, 55-64

14. ,Lee JH Son SM, Kw on HO(2011) Physicochemical composition of Capsosiphon fulvescens according to drying methods. J Korean Soc Food Sci Nutr, 40, $1582-1588$

15. Lee SJ, Seo JK, Shin JH, Lee HJ, Sung NJ (2008) Antioxidant activity of wa-song (Orostachys japonicus A. Berger) according to drying methods. J Korean Soc Food Sci Nutr, 37, 605-611

16. Cha JY, Jeong JJ, Kim YT, Seo WS, Yang HJ, Kim JS, Lee YS (2006) Detection of chemical characteristics in Hamcho (Salicornia herbacea L.) according to harvest periods. J Life Sci, 16, 683-690
17. Jo YC, Ahn JH, Chon SM, Lee KS, Bae TJ, Kang DS (2002) Studies on pharmacological effects of glasswort (Salicornia herbacea L.). Korean J Medicinal Crop Sci, 10, 93-99

18. Cho YS, Kim SI, Han YS (2008) Effects of slander glasswort (Salicornia herbacea L.) extract on improvements in bowel function and constipation relief. Korean J Food Sci Technol, 40, 326-331

19. Pichiah PBT, Cha YS (2015) Salicornia herbacea prevents weight gain and hepatic lipid accumulation in obese ICR mice fed a high-fat diet. J Sci Food Agric, 95, 3150-3159

20. Shin MG, Lee GH (2013) Spherical granule production from micronized saltwort (Salicornia herbacea) powder as salt substitute. Prev Nutr Food Sci, 18, 60-66

21. Chung YC, Chun HK, Yang JY, Kim JY, Han EH, Kho YH, Jeong HG (2005) Tungtungmadic acid, a novel antioxidant, from Salicornia herbacea. Arch Pharm Res, 28, 1122-1126

22. Jang HS, Kim KR, Choi SW, Woo MH, Choi JH (2007) Antioxidant and antithrombus activities of enzymetreated Salicornia herbacea extracts. Ann Nutr Metab, 51, 119-125

23. Cha JY, Jeon BS, Kim BK, Kang HY, Cho YS (2005) Physiological effect of Hamcho yogurt on streptozotocininduced diabetic rats. J Life Sci, 15, 619-625

24. Han EH, Kim JY, Kim HG, Chun HK, Chung YC, Jeong HG (2010) Inhibitory effect of 3-caffeoyl-4-dicaffeoylquinic acid from Salicornia herbacea against phorbol esterinduced cyclooxygenase-2 expression in macrophages. Chem Biol Interact, 183, 397-404

25. Kim MS, Lee JN, Seong HJ, Kim DH, Sohn HY (2016) Changes in in vitro antioxidant and antithrombosis activities of Salicornia europaea according to harvest time. J Life Sci, 26, 1033-1040

26. Lee JN, Kim MS, Kim DH, Sohn HY (2016) Anti-oxidation and anti-thrombosis activities of different parts of Salicornia herbacea L. Microbiol Biotechnol Lett, 44, 311-316

27. Kong CS, Kim YA, Kim MM, Park JS, Kim JA, Kim SK, Lee BJ, Nam TJ, Seo Y (2008) Flavonoid glycosides isolated from Salicornia herbacea inhibit matrix metalloproteinase in HT1080 cells. Toxicol In Vitro, 22, 1742-1748

28. Kim MJ, Jun HY, Kim JH (2015) Anti-obesity effect of Korean Hamcho (Salicornia herbacea L.) powder on high-fat diet-induced obese rats. J Nutr Health, 48, 
123-132

29. Ryu DS, Kim SH, Lee DS (2008) Immunomodulating activity of Salicornia herbacea extract. Kor J Microbiol Biotechnol, 36, 135-141

30. Ryu DS, Kim SH, Lee DS (2009) Anti-proliferative effect of polysaccharides from Salicornia herbacea on induction of $\mathrm{G} 2 / \mathrm{M}$ arrest and apoptosis in human colon cancer cells. J Microbiol Biotechnol, 19, 1482-1489

31. Kim MS, Seong HJ, Sohn HY (2016) In-vitro antithrombosis activity of different parts of Sorbus commixta from Ulleung island. J Life Sci, 26, 289-295

32. Kim MS, Shin WC, Kang DK, Sohn HY (2016) Anti-thrombosis activity of sinapic acid isolated from the lees of Bokbunja wine. J Microbiol Biotechnol, 26, 61-65
33. Sweeney JD, Hoerning LA, Behrens AN, Novak E, Swank RT (1990) Thrombocytopenia after desmopressin but absence of in vitro hypersensitivity to ristocetin. Am J Clin Pathol, 93, 522-525

34. Singleton VL, Orthofer R, Lamuela-Raventos RM (1999) Analysis of total phenols and other oxidation substrates and antioxidants by means of Folin-Ciocaleau reagent. Methods Enzymol, 299, 152-178

35. Usenik V, Fabcic J, Stampar F (2008) Sugars, organic acids, phenolic composition and antioxidant activity of sweet cherry (Prunus avium L.). Food Chem, 107, 185-192 